\title{
Chronic hepatitis B infection in male homosexuals
}

\author{
P. SKINHØJ11, G. HØYBYE ${ }^{1}$, B. HENTZER ${ }^{1}$, V. FABER ${ }^{1}$, AND H. POULSEN ${ }^{2}$
}

From the ${ }^{1}$ Department of Infectious Diseases, Rigshospitalet, Copenhagen, and ${ }^{2}$ Department of Pathology'. Hvidovre Hospital, Copenhagen, Denmark

SUMMARY Ten cases of hepatitis B virus infection were identified among asymptomatic male homosexuals. These patients shared a number of characteristics:

A subclinical origin and course of infection;

Persistence of $\mathrm{HB}_{\mathrm{s}} \mathrm{Ag}$ for periods exceeding six to 25 months;

Persistent GPT elevation of two to five times upper normal limit;

Morphological changes in the liver with portal and parenchymal inflammation (chronic persistent hepatitis, six cases; non-specific reactive hepatitis, 2 cases; cirrhosis and acute hepatitis with signs of chronicity, one case each).

$\mathrm{HB}_{\mathrm{e}} \mathrm{Ag}$ was found in six cases, anti-HB $\mathrm{H}$ in none.

These results indicate that screening for hepatitis B should be performed whenever these individuals come under medical attention in order to detect asymptomatic chronic liver diseases and to detect these silent vectors of an infection that presently shows an increased frequency among homosexuals.

The maintenance of hepatitis $B$ infection appears to be associated with the existence of virus carriers in certain subgroups of the population, for example, drug addicts, institutionalised mentally retarded children, patients treated in haemodialysis units, and healthy individuals from some tropical areas (Szmuness, 1975).

In some areas male homosexuals have also been found to be a possible reservoir of infection as an $\mathrm{HB}_{\mathrm{s}} \mathrm{Ag}$ carrier rate of 3 to $6 \%$ has been documented (Fulford et al., 1973; Jeffries et al., 1973; Szmuness et al., 1975; Coleman et al., 1977; Dietzman et al., 1977).

In order to characterise this $\mathrm{HB}_{\mathrm{s}} \mathrm{Ag}$ carrier group we undertook a prospective study of $\mathrm{HB}_{\mathrm{s}} \mathrm{Ag}$ carriers identified by screening asymptomatic homosexuals.

\section{Material and methods}

Six patients were identified by examination of 50 apparently healthy homosexuals who were members of a political organisation. Three further cases were detected in our department during treatment for

Received for publication 2 January 1979 unrelated acute infections, and one was seen as a contact person of a patient with acute hepatitis B.

All cases had a liver biopsy performed, and they were followed for six to 25 (mean 14) months by repeated serological examinations. Three patients had a further biopsy after nine to 12 months.

$\mathrm{HB}_{\mathrm{s}} \mathrm{Ag}$ was detected by a commercial enzyme immuno-assay (Hepanosticon ${ }^{\mathrm{R}}$, Organon Technica). $\mathrm{HB}_{\mathrm{e}} \mathrm{Ag}$ and anti-HBe were identified by an agar gel double diffusion technique (Skinhøj et al., 1976). Liver function tests included SGPT, basic phosphatases, bilirubin, prothrombin, albumin, and $\operatorname{IgA}$, IgG, and IgM.

Liver biopsy interpretation was performed according to the classification published by two international groups (Anthony et al., 1978; Lancet, 1977).

The number of $\mathrm{HB}_{\mathrm{s}} \mathrm{Ag}$-containing hepatocytes (ground-glass hepatocytes) was evaluated by an orcein stain (Poulsen and Christoffersen, 1979).

\section{Results}

The 10 individuals who were found to be positive for $\mathrm{HB}_{\mathrm{s}} \mathrm{Ag}$ shared a number of features in common. All were asymptomatic and anicteric. Nine had had no preceding acute episode resembling acute hepatitis or any known origin of infection; one 
previous drug addict had had two episodes of jaundice six years previously. Physical examination was normal in all cases.

The case histories disclosed no remarkable infections. However, seven patients had had syphilis, and most had experienced several Neisserial infections.

During the study period all cases remained $\mathrm{HB}_{\mathrm{s}} \mathrm{Ag}$ positive and asymptomatic. Biochemical tests showed moderately elevated SGPT values in all cases, while six cases had elevated IgG and/or IgM, and four had borderline abnormal values for bilirubin (Table).

$\mathrm{HB}_{\mathrm{e}} \mathrm{Ag}$ was found persistently in one subject and intermittently in a further five, while four cases were negative for this antigen. No correlation with the biochemical tests could be demonstrated for those positive and negative for $\mathrm{HB}_{\mathrm{e}} \mathrm{Ag}$. Anti-HBe was not found in any case.

The initial liver biopsy specimens (Table) showed mononuclear inflammatory changes, mainly in the portal tracts, corresponding to a morphological diagnosis of chronic persistent hepatitis in six cases, non-specific reactive hepatitis in two, and acute hepatitis with signs of chronicity in one case.

Orcein-positive, $\mathbf{H B}_{\mathrm{s}} \mathrm{Ag}$-containing hepatocytes were seen in moderate numbers in seven patients. The presence of these cells did not correlate with the presence of $\mathrm{HB}_{\mathrm{e}} \mathrm{Ag}$ in serum.

In patient 6 the first biopsy specimen was rather small but gave a strong suspicion of cirrhosis. A repeat biopsy taken nine months later showed a typical macronodular cirrhosis, probably posthepatitic, with orcein-positive cells.

A repeat biopsy at 12 months in patient 5 showed typical chronic persistent hepatitis and in patient 2 showed unchanged non-specific inflammation with orcein-positive cells.

\section{Discussion}

The present group of clinically healthy $\mathrm{HB}_{\mathrm{s}} \mathrm{Ag}$ carriers identified among male homosexuals is distinctly different from those found in surveys of blood donors, pregnant women, and general hospital patients from the same area (Reinicke et al., 1972; Skinhøj, 1975; Skinhøj et al., 1976). Although asymptomatic and without a history of acute hepatitis, all in the homosexual group showed evidence of chronic liver diseases. Morphologically this included one case of cirrhosis and six cases of chronic persistent hepatitis. In contrast, the $\mathrm{HB}_{\mathbf{s}} \mathrm{Ag}$ carriers in the blood donor group had normal biochemical results and mainly normal histological findings.

Thus the finding of $\mathrm{HB}_{\mathbf{s}} \mathrm{Ag}$ in asymptomatic homosexuals appears to indicate chronic hepatitis, and these cases should, therefore, be evaluated for liver disease when detected and they should be offered regular control for evaluation of the prognosis.

The reason for the discrepancy between the different groups of $\mathrm{HB}_{\mathbf{s}} \mathrm{Ag}$ carriers is not clear, but a possible explanation is that they represent differences in the duration of infection. Most blood donors are assumed to be carrying $\mathbf{H B}_{\mathbf{s}} \mathbf{A g}$ after childhood infection (Feinman et al., 1973; Skinhøj, 1975), while the homosexuals may be infected primarily as adults.

However, other explanations may also be considered: differences in the route of infection, concomitant or previous infection with other agents, or differences in hormonal or genetic factors. Such factors, however, could not be elucidated in the present study.

The homosexual group of patients also differed from other healthy $\mathrm{HB}_{\mathrm{s}} \mathrm{Ag}$ carriers in the presence of $\mathrm{HB}_{\mathrm{e}} \mathrm{Ag}$. This antigen is closely associated with

Table Biochemical and histological features in 10 cases of asymptomatic chronic hepatitis B infection

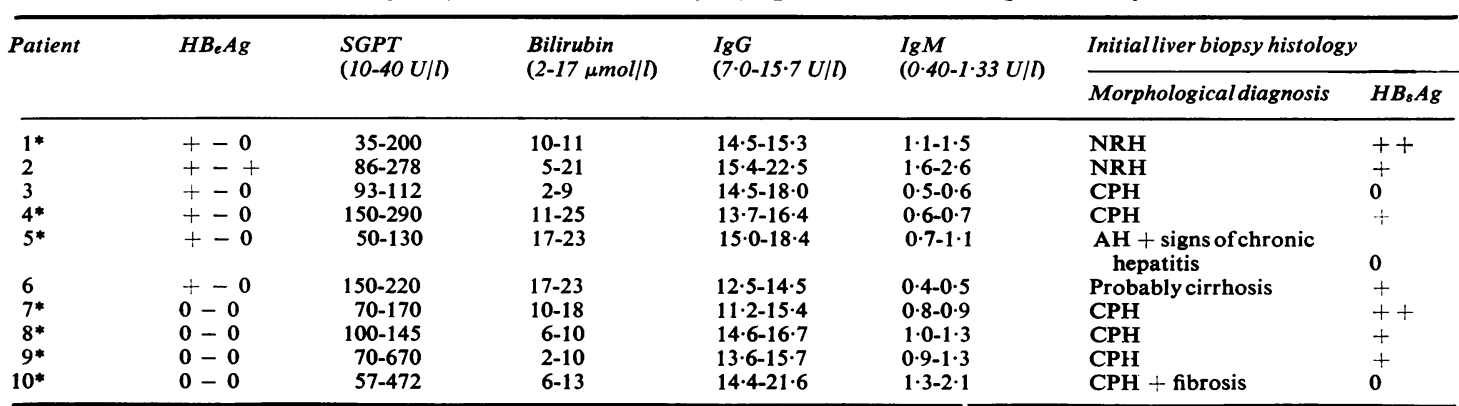

Figures represent range values; figures in parentheses are normal range.

* Patients with previous syphilis.

NRH = non-specific reactive hepatitis; $\mathbf{C P H}=$ chronic persistent hepatitis; $\mathbf{A H}=$ acute hepatitis; $\mathbf{H B}_{\mathbf{s}} \mathbf{A g}$ evaluated by $\mathbf{O r c e i n}_{\mathrm{s}}$ staining: $+0-4$ cells per lobule $;++5-15$ cells per lobule. 
infectivity and is usually found in infected haemodialysis patients, Down's syndrome patients, and other carriers with proven infectivity (Magnius and Espmark, 1972; Nordenfelt and AndrénSandberg, 1976; Skinhøj et al., 1976). Healthy blood donor carriers are usually anti-HBe positive, and this appears to indicate a low degree of infectivity (Skinhøj et al., 1976). None of the homosexuals seen in this study had anti-HBe, while six out of 10 were e-antigen positive at least once. A similar result was obtained in another recent study (Simmons et al., 1977). Thus this group should be regarded as potentially infectious virus carriers.

The presence of 3 to $6 \%$ of $\mathrm{HB}_{\mathrm{s}} \mathrm{Ag}$ positive individuals in the homosexual subpopulation represents a reservoir of infection and may well explain the reported high incidence of acute hepatitis B in this group (Heathcote and Sherlock, 1973; Szmuness et al., 1975).

It also seems warranted that uninfected homosexuals in areas with a documented number of $\mathrm{HB}_{\mathrm{s}} \mathrm{Ag}$ carriers should be offered hepatitis $\mathrm{B}$ vaccine when this becomes available.

The data in the present study indicate that male homosexuals should be studied for the presence of $\mathrm{HB}_{\mathrm{s}} \mathrm{Ag}$ whenever they are in contact with medical institutions in order that infectious hepatitis B virus carriers as well as cases of asymptomatic chronic liver disease may be detected.

\section{References}

Anthony, P. P., Ishak, K. G., Nayak, N. C., Poulsen, H. E., Scheuer, P. J., and Sobin, L. H. (1978). The morphology of cirrhosis. Journal of Clinical Pathology, 31, 395-414.

Coleman, J. C., Waugh, M., and Dayton, R. (1977). Hepatitis B antigen and antibody in a male homosexual population. British Journal of Venereal Diseases, 53, 132-134.

Dietzman, D. E., Harnisch, J. P., Ray, C. G., Alexander, E. R., and Holmes K. K. (1977). Hepatitis B surface antigen $\left(\mathrm{HB}_{\mathrm{s}} \mathrm{Ag}\right)$ and antibody to $\mathrm{HB}_{\mathrm{s}} \mathrm{Ag}$. Journal of the American Medical Association, 238, 2625-2626.

Feinman, S. V., Berris, B., Sinclair, J. C., Wrobel, D. M., Alter, H. J., and Holland, P. V. (1973). Relation of hepatitis-B-antigen subtypes in symptom-free carriers to geographical origin and liver abnormalities. Lancet, 2, 867-869.

Fulford, K. W. M., Dane, D. S., Catterall, R. D., Woof, R., and Denning, J. V. (1973). Australia antigen and antibody among patients attending a clinic for sexually transmitted diseases. Lancet, 1, 1470-1473.

Heathcote, J., and Sherlock, S. (1973). Spread of acute type-B hepatitis in London. Lancet, 1, 1468-1470.

Jeffries, D. J., James, W. H., Jefferiss, F. J. G., MacLeod, K. G., and Willcox, R. R. (1973). Australia (hepatitisassociated) antigen in patients attending a venereal disease clinic. British Medical Journal, 2, 455-456.

Lancet (1977). Acute and chronic hepatitis revisited. Review by an international group. Lancet, 2, 914-919.

Magnius, L. O., and Espmark, J. A. (1972). New specificities in Australia antigen positive sera distinct from the le Bouvier determinants. Journal of Immunology, 109, 1017-1021.

Nordenfelt, E., and Andrén-Sandberg, M. (1976). Dane particle-associated DNA polymerase and e-antigen: relation to chronic hepatitis among carriers of hepatitis B surface antigen. Journal of Infectious Diseases, 134, 85-89.

Poulsen, H., and Christoffersen, P. (1979). Atlas of Liver Biopsies. Munksgaard, Copenhagen; Lippincott, Philadelphia.

Reinicke, V., Dybkjaer, E., Poulsen, H., Banke, O., Lylloff, K., and Nordenfelt, E. (1972). A study of Australia-antigen-positive blood donors and their recipients with special reference to liver histology. New England Journal of Medicine, 286, 867-870.

Simmons, P. D., Islam, M. N., Knott, S., Banatvala, J. E., and Supran, M. (1977). e-antigen among male homosexual patients. British Medical Journal, 4, 1458.

Skinhøj, P. (1975). Epidemiology of hepatitis B antigen and antibody in hospital patients in Copenhagen. Scandinavian Journal of Infectious Diseases, 7, 85-89.

Skinhøj, P., Cohn, J., and Bradburne, A. F. (1976). Transmission of hepatitis type B from healthy $\mathrm{HB}_{\mathrm{s}} \mathrm{Ag}$ positive mothers. British Medical Journal, 1, 10-11.

Szmuness, W. (1975). Recent advances in the study of the epidemiology of hepatitis B. American Journal of Pathology, 81, 629-650.

Szmuness, W., Much, M. I., Prince, A. M., Hoofnagle, J. H., Cherubin, C. E., Harley, E. J., and Block, G. H. (1975). On the role of sexual behaviour in the spread of hepatitis B infection. Annals of Internal Medicine, 83, 489-495.

Requests for reprints to: Dr P. Skinhøj, Department of Infectious Diseases, Rigshospitalet M7721, DKCopenhagen, 2200 N Denmark. 